\title{
A Vermetid Gastropod with Complex Intracapsular Cannibalism of Nurse Eggs and Sibling Larvae and a High Potential for Invasion ${ }^{1}$
}

\author{
Megumi F. Strathmann and Richard R. Strathmann ${ }^{2}$
}

\begin{abstract}
A vermetid gastropod, previously unreported from the Pacific Ocean, was found at $\mathrm{O}^{\prime} \mathrm{ahu}$, Hawai $\mathrm{i}$, in aquariums at the Kewalo Marine Laboratory, in fouling communities on docks, and on intertidal and shallow subtidal coral rubble. It also occurs on coral rubble in Florida. Eggs, or nurse eggs, and early embryos are about $100 \mu \mathrm{m}$ in diameter. Young are brooded in 1-13 stalked capsules attached inside the tubular shell. Intracapsular development involves an unusual complex adelphophagy (sibling cannibalism). Most eggs are nondeveloping nurse eggs. Ten to 20 eggs develop into apparently normal small veligers. Of these most arrest as small veligers, but a few grow to hatch as large pediveligers or juveniles. The species has a high potential for invasion and establishment following maritime transport or natural rafting. Protected intracapsular development ends with the release of crawling hatchlings that also produce mucous threads on which they can drift. Juveniles settle readily on hard substrata. An apparent rarity or absence of males suggests long-term sperm storage, hermaphroditism, or parthenogenesis, any of which could aid colonization. Adults and juveniles occur in fouling communities and can survive extended periods in still seawater and at low food levels. The species' global distribution and history of invasions are unknown. We predict widespread distribution and invasions in warm waters.
\end{abstract}

The small vermetid gastropod described here was recognized in 1970 on the walls of outdoor aquariums at the Kewalo Marine Laboratory in Honolulu (M. Hadfield, pers. comm.). They were very small specimens that were brooding capsules attached to the inside of the tube. Hadfield noted that the developmental mode differed from any described for gastropods in that more than one size of veliger was present in the capsules.

Here we describe this unusual form of adelphophagy (sibling cannibalism), which in-

1 This research was supported by NSF grant IBN0113603 to R.R.S., ONR Award N00014-03-1-0078 to M. G. Hadfield, the Kewalo Marine Laboratory, the Smithsonian Marine Station, and the Friday Harbor Laboratories. Manuscript accepted 28 February 2005.

${ }^{2}$ Friday Harbor Laboratories, University of Washington, 620 University Road, Friday Harbor, Washington 98250. (Correspondence to R. R. Strathmann, email: rrstrath@u.washington.edu).

Pacific Science (2006), vol. 60, no. 1:97-108

(C) 2006 by University of Hawai'i Press

All rights reserved volves intracapsular feeding on both nurse eggs and small but well-formed sibling veligers. Many animals have encapsulated larvae that feed on nurse eggs (ova or arrested embryos) or abnormal embryos, but it is extremely rare for capsules to include nondeveloping nurse eggs, well-formed larvae arrested at an early stage, and siblings that complete development. A similar mix of undeveloped nurse eggs and arrested but normal siblings has been described from encapsulated development of some spionid annelids (Blake and Kudenov 1981, Gibson 1997, Duchene 2000, Gibson and Gibson 2004). To our knowledge, such development is previously unreported for gastropods.

The species is also of interest because it possesses traits that confer a high potential for invasion by maritime transport and subsequent establishment of populations. We found small vermetid specimens with identical adult morphology and reproductive traits on the Atlantic coast of Florida. The species may be widespread in warm marine waters. We therefore include here a description of traits 
visible in live adults that will aid recognition of the species wherever it is found.

We could not assign this vermetid to a known species with certainty, though it resembles a species that Bieler (1995) found in the Azores, which in turn resembles Thylaeodus rugulosus (Monterosato, 1878), a species originally described from the Mediterranean. Assignment to a genus is also uncertain because of ongoing taxonomic revisions concerning vermetids (R. Bieler and T. Rawlings, pers. comm.). In the meantime, we refer to this gastropod as Hadfield's vermetid, because M. Hadfield (pers. comm.) first recognized its unusual adelphophagy.

\section{MATERIALS AND METHODS}

Specimens were collected on O'ahu, Hawai' $i$, from aquariums at Kewalo Marine Laboratory (KML), situated at the channel opening of Kewalo Basin (February to March 1995 and January to March 2002), from racks submerged for a fouling study at Ford Island in Pearl Harbor (February to March 2002 and March 2003), from floating docks at Rainbow Marina in East Loch of Pearl Harbor (March 2003), and from intertidal and shallow subtidal coral rubble at the base of a seawall at Kewalo Park, Honolulu, and shoreward of a reef opening at Kualoa Park at the north end of Kāne'ohe Bay (March 2003). We examined more than 150 living specimens from $\mathrm{O}^{\prime} \mathrm{ahu}$ during spring months. Colleagues examined additional specimens for reproductive state in August and November 2002. We also collected two brooding adults on shallow rubble at Peanut Island, Florida, in May 2003.

Adult snails were freed from their tubes by breaking the shell and severing the columellar muscle. Some voucher specimens were relaxed with $\mathrm{MgCl}_{2}$, transferred to $4 \%$ formaldehyde $(10 \% \mathrm{~V} / \mathrm{V}$ formalin in filtered seawater), then transferred to $70 \%$ ethanol. Other voucher specimens were preserved directly in 80 to $100 \%$ ethanol. Voucher specimens (collected at Ford Island, Pearl Harbor, Hawai'i) are at the Bernice P. Bishop Museum, Honolulu, Hawai'i. One whole specimen (Accession No. 2002.053, врвм catalog no. 264015) has the underside of one whorl broken open; the living specimen visible inside had typical mantle coloration and possibly a dorsal mantle cleft. A brooding adult specimen (врвм cat. no. 264016) was removed from its shell and preserved with three of the five capsules of the brood. Other specimens were deposited аs врвм catalog numbers 264017 to 264031 .

From a few specimens, opercula and radulae were excised, cleaned of soft tissue by brief treatment with $3 \%$ sodium hypochlorite followed by a distilled water rinse, and mounted in water on slides for microscopy or photography.

For observation of in vitro development, brood capsules, some with the stalk attached to a piece of shell, were transferred to small plastic petri dishes containing seawater that had been filtered $(0.5 \mu \mathrm{m})$, microwave-heated to just below boiling, cooled overnight, and aerated by swirling. Water was changed daily.

\section{RESULTS}

\section{Adult Traits}

Though the identity of the species is uncertain, the complex mode of intracapsular adelphophagy distinguishes it from other vermetids in which development has been observed. We include here details of adult traits that in combination with the unusual adelphophagy will aid field identifications for studies of the biogeography and invasive spread of this species.

The adult shell consists of a protoconch and four to seven whorls of tubular teleoconch variously coiled. Individuals attached to flat surfaces form an orderly coil growing off to one side (Figure 1) or stack whorls into an irregular pile. Coils usually end in a straight upright section that tapers slightly to a nearly circular aperture (Figure 1). This terminal tube is thinner-walled and more finely ridged than the older shell. The outer surface of the shell is usually a distinctive red brown but may be gold brown, tan, or pink. The shell has transverse ridges at more or less regular intervals but no obvious longitudinal sculpture. Recumbent whorls usually bear traces of previous upright sections because 

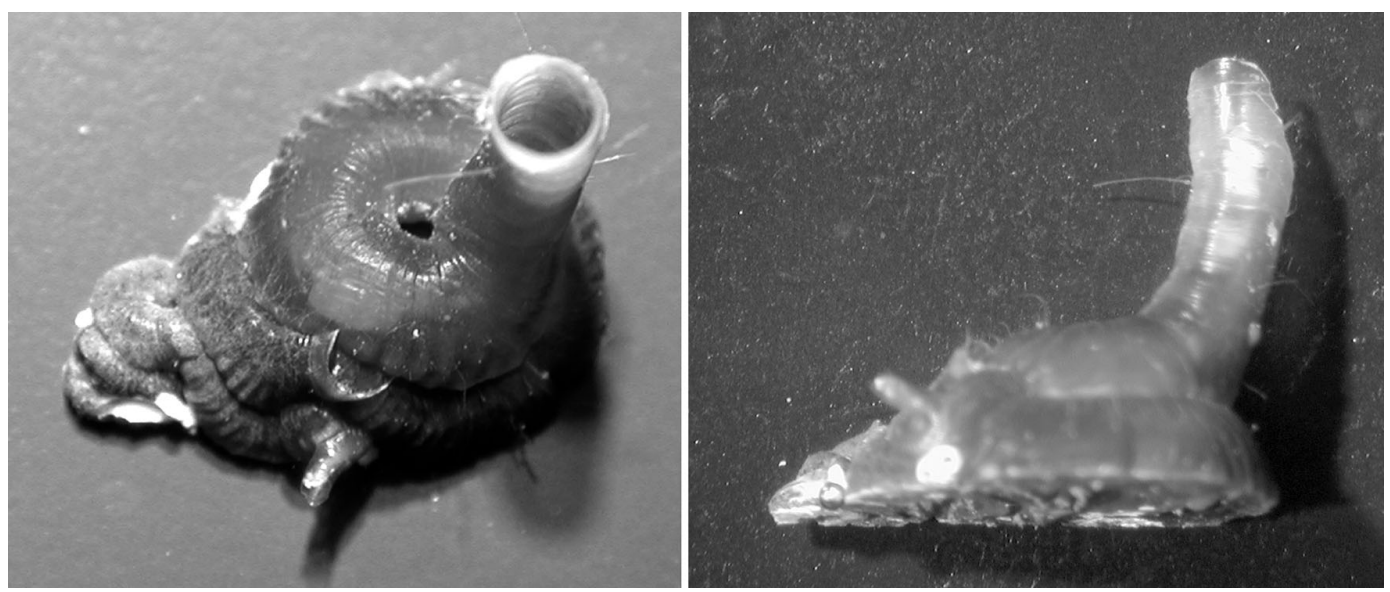

Figure 1. Top view (left) and right side (right) view of a large adult with a small specimen attached to a lower whorl. The tube coils counterclockwise and slightly off center ending in an upright section that tapers to a thin-walled aperture. The aperture is $0.99 \mathrm{~mm}$ in outer diameter and $5.0 \mathrm{~mm}$ above the substratum. The coiled whorls cover a basal area 5.2 by $3.8 \mathrm{~mm}$. A remnant of a previous upright tube is just below center in top view; below this remnant is the upright terminal tube of a small individual.

the upright section is lost when a new whorl is added; the new whorl ends in a new upright. Some specimens from tangled mats of fouling have shells with whorls piled in a high stack and a long upright section; others have shells loosely spiraled into a corkscrew shape, with or without a straight terminal section. Plasticity in coiling is known from other vermetids (Schiaparelli and Cattaneo-Vietti 1999). The inner shell surface is usually a polished red brown but sometimes paler. We found no lamellae on the inner surface of the tube in any whorl nor at the attachment point of the columellar muscle.

Adults are so small that they could easily be mistaken for juveniles of other vermetid species. Brooding adults from flat-walled aquariums at KML had tubes 3.3 to $5.3 \mathrm{~mm}$ across the coil of recumbent whorls $(n=14)$ ending in an upright straight terminal section with the aperture 2.0 to $5.3 \mathrm{~mm}$ above the substratum. Brooding adults from fouling on relatively flat surfaces on racks at Ford Island were 2.2 to $7.1 \mathrm{~mm}$ across the coiled whorls, with apertures 3.3 to $7.7 \mathrm{~mm}$ above the substratum $(n=7)$. The external tube diameter of brooding adults at KML averaged $1.1 \mathrm{~mm}$ on the largest recumbent whorl $(n=8$, range
$1.0-1.4 \mathrm{~mm})$ and $0.9 \mathrm{~mm}$ at the aperture $(n=15$, range $0.8-1.1 \mathrm{~mm})$. The tubes of Ford Island brooding adults averaged $1.2 \mathrm{~mm}$ external diameter on the recumbent whorl ( $n=4$, range $1.1-1.3 \mathrm{~mm}$ ) and $0.9 \mathrm{~mm}$ at the aperture $(n=6$, range $0.9-1.0 \mathrm{~mm})$. Specimens from coral rubble in shallow water at Kewalo Basin and Kualoa Park were of similar size, as were the specimens from Peanut Island, Florida.

The tiny barrel-shaped protoconch (Figure 2) usually is buried in the whorls of the teleoconch. At attachment, the protoconch is positioned on its side with the outer apertural edge against the substratum. It is soon surrounded by one-half to a full whorl of teleoconch attached to the substratum (Figure 3). The initially formed protoconch has a slightly granular or irregularly malleate surface (Figure 2). Subsequent protoconch whorls are smooth-surfaced, somewhat flat-sided, transparent, and colorless to yellow brown with light to dark brown at the sutures. Counting the small initial shell as whorl 1 , the complete protoconch has three or slightly more whorls. The protoconch was at least partly visible on the underside of most specimens taken from flat aquarium walls at KML: average 


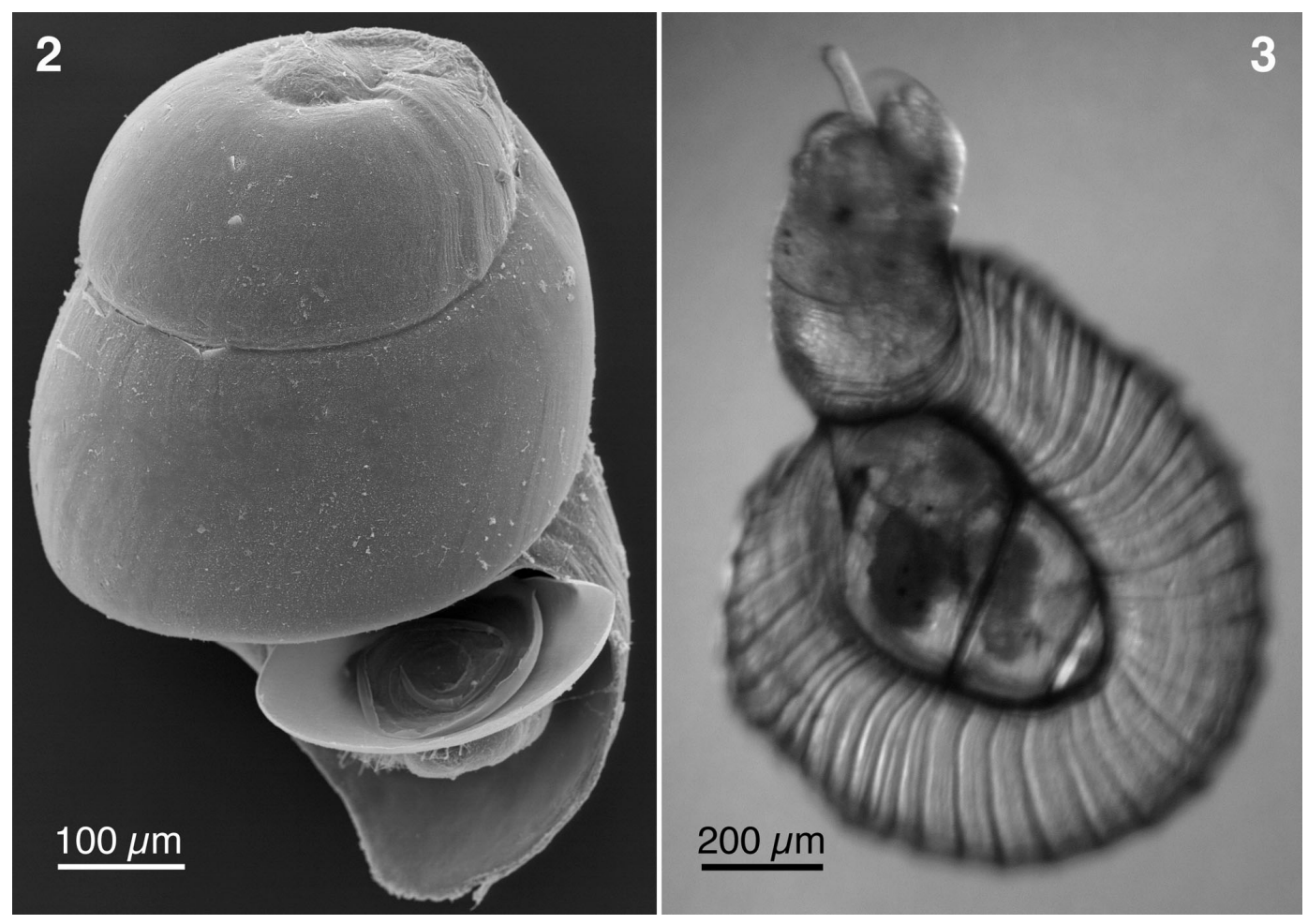

FIgUREs 2-3. (2) A freely crawling hatchling that no longer has a velum (SEM). The protoconch has an initial roughsurfaced whorl to which slightly more than two smooth whorls have been added. The specimen is tilted to show the thin operculum and its spiraled flange. No teleoconch has yet developed. (3) A recently attached juvenile. The protoconch lies on its side and the teleoconch has been added in a counterclockwise recumbent whorl with a short upright tube. The teleoconch has regular transverse ridging but no distinct longitudinal sculpture. The visceral body visible inside the protoconch is linked by a thin connection to head and foot at the aperture. Eyes, cephalic tentacles, and pedal tentacles are present. The operculum is faintly visible behind the extended small foot.

length was $442 \mu \mathrm{m}(n=15$, median $=453$ $\mu \mathrm{m}$, range $346-547 \mu \mathrm{m})$ and average width was $294 \mu \mathrm{m} \quad(n=10$, median $=308 \mu \mathrm{m}$, range 157-379 $\mu \mathrm{m})$. Protoconchs were often lost or not visible on specimens taken from dense fouling communities; those measured had length about $410 \mu \mathrm{m}(n=2)$ and width about $350 \mu \mathrm{m}(n=2)$. (Note: sizes of protoconchs measured on field specimens may err on the small side because the margins of the protoconch are obscured by surrounding teleoconch.)

The operculum (Figures 2, 4) is nearly circular, thin, transparent to a translucent light yellow brown, and flexible in living specimens. The thin flexible edge projects be- yond the edges of the foot. The outer surface is concave and bears an upright flange that openly spirals, in three-fourths to one full whorl, from the center to the edge of the operculum. The inner opercular surface is centrally granulated but lacks the projecting mamilla present in some vermetids (Hadfield et al. 1972). In hatchlings the operculum is as large as the aperture (Figure 2), but in adults the opercular diameter is only $72-87 \%$ of the diameter of the aperture (Figure 5). This small diameter may allow the deep retreat within the coiled shell that occurs when individuals are disturbed.

The head (Figure 6) is not especially broad (as in some species of Serpulorbis) but does 
bear a slight longitudinal flange on each side that extends from the cephalic tentacles back along the long "neck" into the deep mantle cavity. Two cephalic tentacles are slender and short, each with a small eye at the base. Two pedal tentacles, if contracted, are stouter but about the same length as the cephalic tentacles; they are thinner and up to twice as long if the snail is extended at the aperture, as it is when feeding or grooming the shell edge. The pedal tentacles flank a sturdy snout with a large mouth. The foot is reduced to a propodial pad in front of the mouth and a columnar metapodium bearing the operculum.

The radula (Figure 7) has a typical vermetid pattern of a large central tooth with one lateral and two marginal teeth on each side. The radulae of large specimens $(n=3)$ had 25 to 27 rows of teeth. One unattached juvenile that had not yet formed a tubular teleoconch had a tiny radula, $109 \mu \mathrm{m}$ long and 29 $\mu \mathrm{m}$ wide, with 11 rows of formed teeth and faint traces of forming additional teeth.

The living color of the head and anterior body (Figure 6) is a translucent cream to beige tissue sprinkled with pale to bright red or orange spots and opaque white spots, sometimes with an overlay of very small black spots. Commonly, red spots are large and densely packed, so head and anterior neck appear rose to red. With the overlay of fine black spots, the apparent color is sometimes dark red to maroon; some dark specimens lack large patches of bright white. In comparison, pale specimens lack the fine black spots and are sparsely dotted with red but have some white pigment. Some specimens appear bright orange. Red spots under the transparent operculum may form a central dot and two or three peripheral patches. White spots are scattered over the head, foot, and pedal tentacles but are dense on the tips and bases of the cephalic tentacles, on the snout and reduced propodium just below the mouth, and on the sides of the foot, especially near the operculum. The anterior mantle has red and sometimes fine black spots, and the mantle edge has a conspicuous border of alternating red and white. The posterior mantle wall is transparent to translucent with scattered bright orange spots and bright white spots.
In recently settled specimens, red and white pigment may be sparse but the distribution pattern is the same; pigment appears first on the cephalic tentacles, edges of the foot, especially near the operculum, and on the mantle.

The mantle cavity is deep. The anteroventral mantle edge is continuous (Figure 6). The dorsal mantle edge is undivided in small specimens but deeply cleft in brooding adults or adults with gonads containing ova. This dorsal midline cleft allows stalked capsules to be firmly attached to the interior of the shell tube and may be a temporary feature associated with brooding, as in Serpulorbis imbricatus (Nishiwaki 1969). Some nonbrooding large specimens appeared to have a partially developed cleft; the red and white mantle border was narrower or interrupted by a small notch at the dorsal midline. These may have been pre- or postbrooding individuals. A few had gonads containing material that resembled eggs.

\section{Reproduction}

Most large specimens examined in January to March of 1995 and 2002 and in March of 2003 had dorsally cleft mantles and were brooding or had gonads with presumed ova (pale aqua spheroids similar to the nurse eggs in brooded capsules). Of 12 specimens examined in August 2002, 11 did not have cleft mantles and none had a recognizable gonad. Of 21 specimens examined in November 2002, nine had cleft mantles, and of these seven were brooding and two were not brooding but had visible ovaries; of the 12 without a mantle cleft, three had ovaries (one just developing) and nine did not (M. G. Hadfield, pers. comm.). The brooding season thus is at least November through March on O'ahu. Two brooding specimens were found at Peanut Island, Florida, in May 2003.

Males of the species are rare if they occur at all. They are apparently absent during the brooding season. In small and large specimens without dorsally cleft mantles examined January through March, we could not find testes, sperm, or spermatophores as have been described for other vermetid species (Hadfield and Hopper 1980). Specimens isolated 

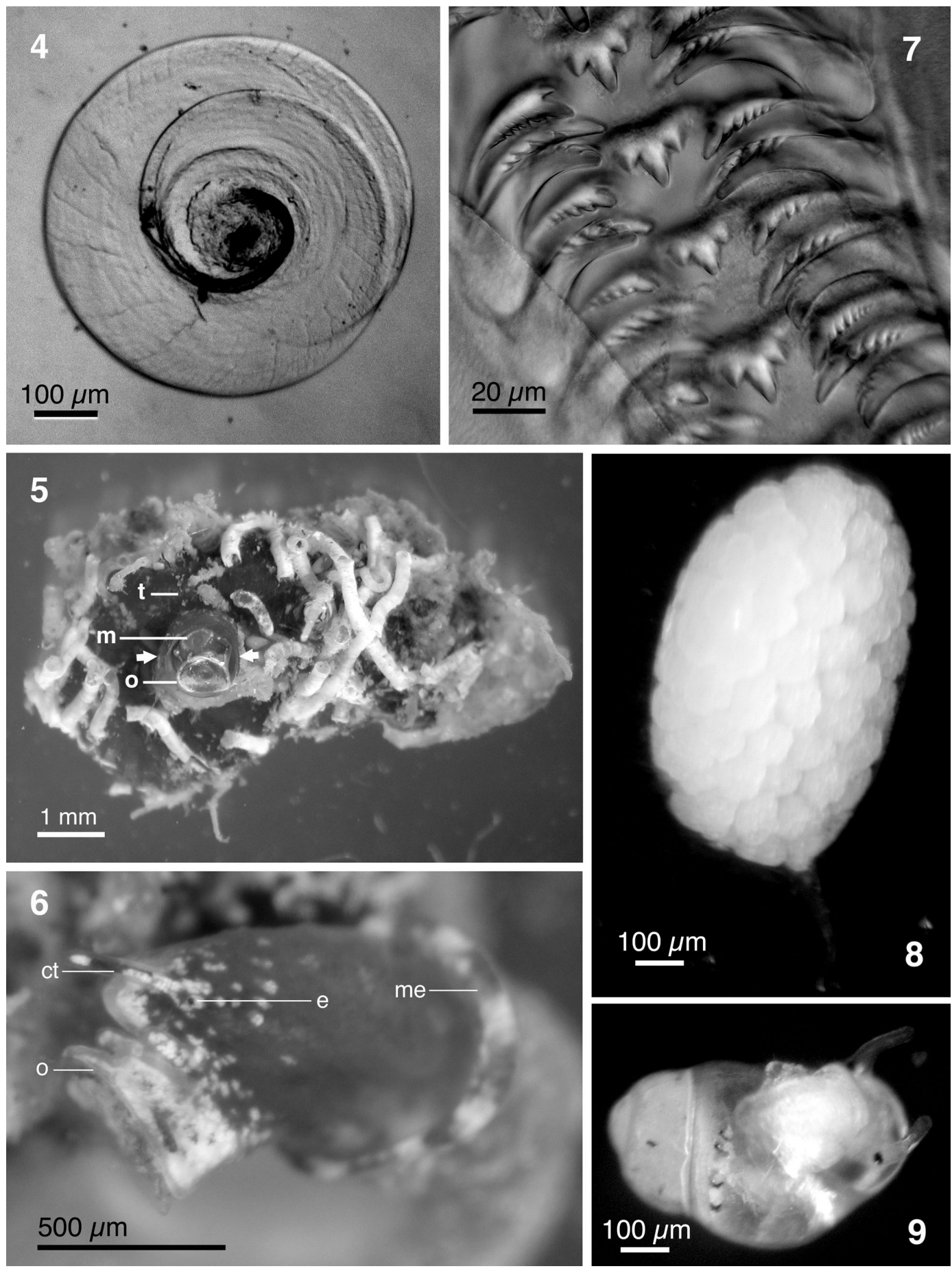
overnight in small bowls of seawater did not release spermatophores. We saw no sperm in microscopic examinations of squash preparations of gonadal tissue. Colleagues found no males among specimens examined in August, November, or January.

\section{Development with Complex Adelphophagy}

Broods comprised up to 13 stalked capsules attached in a row to the inner surface of the shell, usually in the last whorl before the upright terminal tube or about $0.5 \mathrm{~mm}$ from the aperture in more openly coiled forms. Each capsule (Figure 8) initially contained 130 to 200 small eggs and nurse eggs, occasionally more. In five early-stage capsules, mean egg length was $105 \pm 5 \mu \mathrm{m}$ and width was $94 \pm 3 \mu \mathrm{m}$ (mean $\pm \mathrm{SD}$, estimates for each capsule from median dimensions for 10 eggs). Egg color varied among brooders from almost white to pale green, pale blue, and bright aqua.

Up to 18 small veligers initially developed in a capsule, but of these usually only two to five developed to hatching. We compared freshly dissected capsules and observed capsules isolated and maintained in vitro. The numbers of nurse eggs and small veligers declined during development. Intracapsular development thus appeared to be supported by consumption not only of many small nurse eggs or egg-sized embryos but also of small sibling veligers. All small veligers initially had foot and operculum, calcified shell, two velar lobes, paired eyes, and two statocysts; some grew slightly and added to the initial protoconch before development was arrested. The shells of the arrested siblings decalcified and their viscera lost color as development of the large siblings proceeded.

Capsules in vitro released a variety of stages, but some hatched only when no nurse eggs or small sibling veligers remained. Hatchlings ranged from pediveligers (Figure 9) with vela up to $400 \mu \mathrm{m}$ wide to juveniles with no vela, but all could crawl actively on a large foot with a flexible ciliated propodium. The three-whorled protoconchs of hatchlings in vitro ranged in size from 411 to $724 \mu \mathrm{m}$ long and from 352 to $431 \mu \mathrm{m}$ wide.

\section{Geographic Distribution}

We found specimens on both leeward and windward shores of $\mathrm{O}^{`}$ ahu, Hawai' $i$. A. Faucci (pers. comm.) found specimens at other islands in the Hawaiian chain (Kure, Midway, Pearl and Hermes, Lisianski, Maro, French Frigate Shoals, and Necker) and one specimen from Luminao Reef in Guam. We found two brooding specimens at Peanut Island, on the east coast of Florida. One of these had capsules at multiple stages of development with the same mixture of nurse eggs, arrested early-stage veligers, and growing veligers. This mode of complex adelphophagy is so unusual that, together with the adult traits, it indicates that this is the same species as Hadfield's vermetid from $\mathrm{O}^{\prime}$ ahu.

T. Rawlings (pers. comm.) found that specimens from O'ahu and Florida (Peanut

Figures 4-9. (4) An adult operculum, inner surface. The base of the spiral flange on the outer surface is visible through the thin operculum. (5) An adult with serpulid worms and other fouling organisms. The operculum (o) is smaller than the aperture (indicated by two arrows). Above the operculum, white-tipped tentacles flank the dorsally flexed snout. The mouth $(\mathrm{m})$ is open as the radula draws in a debris-laden mucous thread (t) faintly visible above the aperture. (6) A nonbrooding adult, left side view with anterior shell removed. The head color is red from close-packed red spots with an overlay of very fine black spots. Opaque white spots are typically distributed, concentrated on sides of the metapodium, on the tip of the snout, and at the tip and base of the cephalic tentacle. The left eye (e) is visible at the base of left cephalic tentacle (ct). The left pedal tentacle, foot, thin operculum (o), and red-white banded mantle edge (me) are out of focus but visible. The dorsal mantle is uncleft. (7) A radula dissected from an adult. Each row of teeth consists of a large central tooth flanked by one lateral and two marginal teeth on each side. Each tooth has several smaller cusps on each side of a large pointed cusp. The large base of the large central tooth is out of focus below the bases of the flanking lateral and marginal teeth. Part of the odontophore is folded over the bases of the teeth, lower left. (8) Capsule with eggs and embryos. The attachment stalk shows faintly, lower right. (9) A hatched pediveliger. Remnants of velar lobes are present as ciliated ridges behind the eyes. The broad flexible propodium can be extended more than is shown here. 
Island) differed by only 20 of 1,745 base pairs (in a sequence from domains III and IV of small subunit rRNA, I-IV of large subunit rRNA, and two intervening tRNA genes, tRNAVAL and tRNAGLU), supporting the inference of a single species.

\section{Fuveniles}

Hatched pediveligers are negatively buoyant and the velum is so small that they do not swim effectively; however, pediveligers and crawling juveniles can produce mucous threads on which they waft away with a slight water current. Hatchlings on these invisible threads were inadvertently swept into a pipette during water changes of laboratory cultures. In one instance, the mucous thread stretched up to $7 \mathrm{~cm}$ in air before breaking from the juvenile at the water surface. The time from hatching to settlement and metamorphosis in the field is unknown. In the laboratory, advanced pediveligers with reduced velar lobes emerged from capsules and remained free-crawling for 2 days to over a week. They attached to glass or hard plastic, then rapidly grew a surrounding whorl of attached recumbent tube and an upright terminal tube (Figure 3).

\section{Habitat}

Specimens in the field were found attached directly to hard surfaces, usually in small depressions and holes. Intertidal specimens were found on the undersides of coral rock and also on oyster valves attached to the coral rubble but not on surfaces exposed long to air. The only coral rubble areas we searched were semiprotected and had little accumulated sediment. The species occurs in fouling communities in harbors with heavy maritime traffic. Specimens in fouling communities were found attached to shells of oysters and to shell tubes of conspecifics and of another vermetid (Vermetus alii), but not to barnacle plates, and were often associated with encrusting colonies of a bryozoan, Schizoporella sp. At Pearl Harbor (Rainbow Marina) some specimens were covered by sponge or bryozoan colonies, with the vermetid aperture just level with the encrusting surface; empty vermetid shells found under bryozoans may indicate lethal overgrowth.

Juveniles will attach to fiberglass aquarium walls and to glass and some plastics in the laboratory. Collected specimens survived well in flow-through seawater aquariums and tolerated still water. Specimens survived for at least 3 weeks in small covered bowls of standing seawater, changed at most once daily, with little living or detrital food. One specimen survived 12 days without water change and at least 8 more days after a single water change.

\section{DISCUSSION}

\section{Complex Adelphophagy}

Development in which a few large individuals are supported by feeding on nondeveloping nurse eggs or on siblings arrested early in development has long been known to occur in some vermetids (e.g., Aziro and Nishiwaki 1970, Hadfield et al. 1972, Hadfield 1989, Miloslavich and Penchaszadeh 1992, Bieler 1995) and other marine gastropods (Fioroni 1988). Most cases of intracapsular adelphophagy do not extend to cannibalism of siblings that have reached the veliger stage, though it does occur (Miloslavich et al. 2003). In the vermetid Vermetus triquetrus, encapsulated larvae ingest both nurse eggs and abnormal smaller veligers (Calvo and Templado 2004). In capsules of a calyptraeid gastropod, feeding is first on nurse eggs followed by cannibalism among advanced embryos (Miloslavich and Penchaszadeh 2001). Large pediveligers of another calyptraeid feed on recognizable but small and abnormal sibling veligers (Véliz et al. 2001). In the case of Hadfield's vermetid, the small veligers appear normal and some grow additional shell before their development is arrested. We know of no other case among mollusks in which adelphophagy involves both nurse eggs and cannibalism of well-formed siblings with arrested development, but this unusual mode of development has evolved independently in annelids. Some spionid polychaetes, Boccardia species, have a similar mix of undeveloped nurse eggs and ar- 
rested but normal siblings in their brooded egg capsules (Blake and Kudenov 1981, Gibson 1997, Duchene 2000, Gibson and Gibson 2004).

\section{Invasive Potential}

In tracing the origins of mid-Atlantic Azorean vermetids from Mediterranean sources, Bieler (1995) pointed out that sessile, filter-feeding vermetids, with their capsular lecithotrophic mode of development, are well equipped for dispersal by rafting and for long-distance dispersal in the fouling community on ship hulls.

Hadfield's vermetid possesses additional traits that confer a high invasive potential. Brooding and release of offspring as juveniles eliminates many of the risks associated with the precompetent pelagic life of larvae that must feed and grow to reach competence for settlement and metamorphosis. The freely crawling juveniles and sessile juveniles and adults are very small and could easily disperse by natural rafting or by transport with species shipped as food or for aquaculture. Because they tolerate poor-quality seawater and low food levels, they presumably could survive maritime transport in ballast water before settlement and perhaps could settle and reproduce in ballast tanks. Release of offspring as pediveligers and juveniles presumably permits either immediate exploratory crawling and attachment near parents or dispersal by mucous threads to another site (Hughes 1979). Because the juveniles produce long mucous strands and can remain unattached for a long time, they should be capable of substantial transport in currents, as has been demonstrated for other small gastropods (Martel and Diefenbach 1993). Once transported, juveniles' readiness to settle on a range of hard substrata and tolerance of poor water quality would aid in establishing populations.

The mode of mating and reproduction may also aid colonization by a single individual or small numbers of individuals. We do not yet know if this species is gonochoric, hermaphroditic, or parthenogenetic. The apparent absence of males during the brooding season has several possible explanations: (1) Males may become reproductive much earlier in the year than females, with females capable of long-term storage of sperm or spermatophores. In males of Serpulorbis imbricatus, Nishiwaki (1969) found testes well developed during October-March but in a degenerated state when females were depositing and brooding capsules in May-August. Calvo et al. (1998) found that males of Dendropoma petraeum developed gonad 2 months before females. In Hadfield's vermetid, however, we did not see any spermatophores or sperm in squash preparations of tissue taken from brooding adults nor were ripe males and spermatophores seen in large specimens examined in August (2 to 3 months before brooding season) or November (presumably early in the brooding season) (M. G. Hadfield, pers. comm.). (2) The reproductive season of males may be brief. (3) Males may be much smaller than females and have therefore been overlooked. (4) The species may exhibit protandric hermaphroditism as Hadfield (1966) found for Serpulorbis squamigerus. (5) The species may be parthenogenetic or simultaneously hermaphroditic with low male allocation. (6) Males may be present but very rare. Calvo et al. (1998) reported a population of Dendropoma petraeum that was gonochoric but had a preponderance of females (71\%). The apparent absence of males, at least while females are brooding, suggests the possibilities of long-term sperm storage, self-fertilization with low male allocation, or parthenogenesis. Any of these reproductive traits would aid founding of a population by a dispersed individual and invasive spread of this species.

\section{Geographic Range}

Occurrence of Hadfield's vermetid in the mid-Pacific Hawaiian Island chain and in Florida suggests a broad distribution. T. Rawlings (pers. comm.) found only a small divergence of base pairs between specimens from Hawai'i (O'ahu) and Florida (Peanut Island) and between these and a small vermetid from the Azores. At the least, the species occurs in both the Atlantic and Pacific Oceans. It would not be surprising to find this small vermetid in most warm marine waters of the world. 
The geographic origin of Hadfield's vermetid is uncertain. Given its occurrence in the fouling communities on docks and in coral rubble on several shores, it is likely to prove a common member of mixed reef fauna and fouling communities that previously has been overlooked because of its small size. It could have resided in the Hawaiian Islands long before it was first noticed in 1970 .

\section{Distinction from Other Hawaiian Vermetids}

Field identification and recognition of vermetids has been aided by observation of shell and soft-part anatomy, habitat, behavior, and modes of reproduction and development. These traits were well documented for eight species of vermetids of Hawai'i, seven described as new, by Hadfield et al. (1972). Hadfield's vermetid is smaller than any of the eight previously reported species. It differs from Dendropoma gregaria, D. meroclista, D. platypus, D. psarocephala, and D. rbyssocon$c b a$ in that its tube is not entrenched in hard substratum or conspecific shells, nor is the operculum thick, domed, or mamillate on the internal surface. It is not strongly gregarious as is D. gregaria and does not have the constricted aperture of D. meroclista. The second and third whorls of the protoconch are smooth-surfaced, not cancellate or ribbed as are those of D. gregaria, D. rbyssoconcha, and $D$. platypus. It is easily distinguished from Serpulorbis variabilis, which lacks an operculum. It is unlike Vermetus alii in its shell tube, which has axial sculpture and is pale to dark red brown, not smooth and pale to white, and in its operculum, which has less than one, not several, whorls of spiral flange. Hadfield's vermetid is distinguished from Petaloconchus keenae by several features: the shell tube lacks internal lamellae; head and anterior body is pale to dark red with white and black pigment spots, not dark purple to rosy brown, sprinkled with white and yellow (Hadfield et al. 1972), and the mantle border is red and white; eggs and capsules are smaller; encapsulated early veligers do not have a purple black esophagus and later veligers have a green, not red orange, digestive gland.

Hadfield's vermetid may have been in- cluded in previous reports from Hawai $i$. Taylor (1975:86 and pl. IXe-g) described and illustrated planktonic veligers, found from February through July in Kāne'ohe Bay, that may be pediveligers or juveniles of Hadfield's vermetid that entered the plankton by drifting on mucous threads. Taylor's illustration of a newly metamorphosed specimen matches those that we saw hatch and metamorphose in vitro. Hopper (1981) compared reproduction and development of eight Hawaiian vermetid species with those of 11 species from other regions in the world. She mentioned a small vermetid species at Coconut Island in Kāne'ohe Bay as Petaloconchus tokyoensis and listed features of development (her Table 1) that are consistent with those that we observed. None of our Hawaiian specimens matched the brief original description of $P$. tokyoensis (as Vermetus tokyoensis) by Pilsbry (1895:61, pl. I, figs. 9, 10, 11). The description is of the shell only, an internal feature of which was two parietal laminae. Internal shell laminae are not present in our specimens, and a photograph supplied by G. Rosenberg from the Philadelphia Academy of Natural Sciences shows the type of $P$. tokyoensis to have a light-colored and smoothsurfaced shell.

Ladd (1972) named a new species, Petaloconchus (Macrophragma) merkana, from Miocene fossil shells from Palau, Eniwetok, and Bikini and noted that living specimens have been collected from Bikini's Lagoon and from Pearl Harbor, O'ahu, and Midway Atoll in Hawai'i. Ladd found shell internal lamellae to be "shown by many specimens, both fossil and living." Specimens without lamellae might have been Hadfield's vermetid, but the specimen on an oyster shell from Pearl Harbor illustrated in Ladd's pl. 3, fig. 10 is larger $(13.9 \mathrm{~mm})$ and has more whorls than we ever found.

\section{Possible Identity}

One candidate for identity is Thylaeodus rugulosus. Bieler (1995) gave this as a tentative identification for a small vermetid from the Azores with features shared by our specimens from Hawai'i and Florida. Similarities in- 
cluded small size, teleoconch form and sculpture, opercular form, soft-part anatomy, and capsular brooding of a few large crawl-away hatchlings from small green eggs and nurse eggs. Its protoconch size (two and one-half whorls, 700-730 $\mu \mathrm{m}$ long and 390-420 $\mu \mathrm{m}$ wide) is close to that of Hadfield's vermetid. A specimen of the Azorean species differed from specimens from Florida and Hawaici by less than $1.5 \%$ of a 1,745 base-pair sequence (T. Rawlings, pers. comm.). The specimens from the Azores differed in shell and body coloration. Shell tube was white outside and inside, but with $40 \%$ having brown inside. Soft-body color was from pink, white, and purplish pink granules. Color varied in $\mathrm{O}^{\prime}$ ahu specimens, however, and might vary more between separated populations. Operculum was described as filling the aperture, another difference. Bieler's comment on development (capsules filled with dozens of light green eggs, only 3-5 of which developing into embryos, the rest being consumed as nurse yolk) could indicate either a simpler adelphophagy in the Azorean species or the absence of mixed early- and late-stage veligers in a limited sample of capsules. Bieler commented that no velar lobes were observed on intracapsular larvae, but the velar lobes of Hadfield's vermetid are small and might be missed in limited material. Bieler tentatively assigned the small Azorean vermetid to Thylaeodus rugulosus (Monterosato, 1878), a species described from the Mediterranean. Identification of Hadfield's vermetid as T. rugulosus would be indicated if a more extensive examination of broods in new specimens from the Azores and the Mediterranean revealed both nurse eggs and arrested veligers.

Vermetid taxa need reassessment (Keen 1961, Gould 1994, Bieler 1995) and molecular analysis is currently under way (T. Rawlings and R. Bieler, pers. comm.). Revisions of genera are likely to include the small vermetid that we have discussed here.

Perhaps this small vermetid with complex adelphophagy can soon be assigned with confidence to a genus and species. Until then, for studies of reproductive mode and of global invasions, small vermetid adults that match the description given here may be assigned to the widespread species called here Hadfield's vermetid. Whatever name is eventually assigned to this species, its unusual method of development, with capsules containing veligers at both small and large stages, is a useful defining character.

\section{ACKNOWLEDGMENTS}

M. Hadfield provided help and advice throughout the study. B. Nedved discovered and collected specimens at Ford Island in Pearl Harbor. We also thank Richard Chock, A. Faucci, R. Langston, W. Lee, M. Martindale, L. Nederbragt, S. Santagata, M. Schwartz, and E. Seaver for help in laboratory or field; T. Weatherby Carvalho and M. Dunlap for help with scanning electron microscopy; T. Rawlings and Anuschka Faucci for results from their genetic analyses; and R. Bieler, C. Hickman, and an anonymous reviewer for comments on the manuscript.

\section{Literature Cited}

Aziro, K., and S. Nishikawa. 1970. Abnormal cleavage of the food eggs of Serpulorbis imbricatus (Prosobranchia, Vermetidae). Zool. Mag. (Tokyo) 79:92-94.

Bieler, R. 1995. Vermetid gastropods from Sao Miguel, Azores: Comparative anatomy, systematic position and biogeographic affiliation. Acoreana Suppl. 1995:173-192.

Blake, J. A., and J. D. Kudenov. 1981. Larval development, larval nutrition, and growth for two Boccardia species (Polychaeta: Spionidae) from Victoria, Australia. Mar. Ecol. Prog. Ser. 6:175-182.

Calvo, M., and J. Templado. 2004. Reproduction and development in a vermetid gastropod, Vermetus triquetrus. Invertebr. Biol. 123:289-303.

Calvo, M., J. Templado, and P. E. Penchaszadeh. 1998. Reproductive biology of the gregarious Mediterranean vermetid gastropod Dendropoma petraeum. J. Mar. Biol. Assoc. U.K. 78:525-549.

Duchene, J.-C. 2000. Effects of poecilogony and delayed larval emission on recruitment of Subantarctic population of Boccardia 
polybranchia (Polychaeta: Spionidae). Bull. Mar. Sci. 67:311-319.

Fioroni, P. 1988. Die ProsobranchierEntwicklung mit Nahreiern. Zool. Anz. 221:201-247.

Gibson, G. D. 1997. Variable development in the spionid Boccardia proboscidactyla (Polychaeta) is linked to nurse egg production and larval trophic mode. Invertebr. Biol. 116:213-226.

Gibson, G. D., and A. J. F. Gibson. 2004. Heterochrony and the evolution of poecilogony: Generating larval diversity. Evolution 58:2704-2717.

Gould, S. J. 1994. Petaloconchus sculpturatus alaminatus, a new Pliocene subspecies of vermetid gastropods lacking its defining generic character, with comments on vermetid systematics in general. J. Paleontol. 68:1025-1036.

Hadfield, M. G. 1966. The reproductive biology of the California vermetid gastropods Serpulorbis squamigerus (Carpenter, 1857) and Petaloconchus montereyensis Dall, 1919. Ph.D. diss., Stanford University, Stanford, California.

- 1989. Latitudinal effects on juvenile size and fecundity in Petaloconchus (Gastropoda). Bull. Mar. Sci. 45:369-376.

Hadfield, M. G., and C. N. Hopper. 1980. Ecological and evolutionary significance of pelagic spermatophores of vermetid gastropods. Mar. Biol. (Berl.) 57:315-325.

Hadfield, M. G., E. A. Kay, M. U. Gillette, and M. C. Lloyd. 1972. The Vermetidae (Mollusca: Gastropoda) of the Hawaiian Islands. Mar. Biol. (Berl.) 12:81-98.

Hopper, C. N. 1981. The ecology and reproductive biology of some Hawaiian vermetid gastropods. Ph.D. diss., University of Hawai'i at Mānoa, Honolulu.

Hughes, R. N. 1979. Notes on the reproductive strategies of the South African vermetid gastropods Dendropoma corallinaceum and Serpulorbis natalensis. Veliger 21:423427.

Keen, A. M. 1961. A proposed reclassification of the gastropod family Vermetidae. Bull. Br. Mus. (Nat. Hist.) Zool. 7 (3): 183213, pl. 54-55.
Ladd, H. S. 1972. Cenozoic fossil mollusks from western Pacific islands; Gastropods (Turritellidae through Strombidae): Descriptions or citations of 174 representatives of 18 gastropod families from seven island groups. U.S. Geol. Surv. Prof. Pap. 532.

Martel, A., and T. Diefenbach. 1993. Effects of body size, water current and microhabitat on mucous-thread drifting in postmetamorphic gastropods Lacuna spp. Mar. Ecol. Prog. Ser. 99:215-220.

Miloslavich, P., and P. E. Penchaszadeh. 1992. Reproductive biology of Vermetus sp. and Dendropoma corrodens (Orbigny, 1842): Two vermetid gastropods from the southern Caribbean. Veliger 35:78-88.

- 2001. Adelphophagy and cannibalism during early development of Crucibulum auricula (Gmelin, 1791) (Gastropoda: Calyptraeidae) from the Venezuelan Caribbean. Nautilus 115:39-44.

Miloslavich, P., E. Klein, and P. E. Penchaszadeh. 2003. Reproduction of Crepidula navicula Mørch, 1877 and Crepidula aplysioides Reeve, 1859 (Caenogastropoda) from Morrocoy and La Restinga Lagoon, Venezuela. Nautilus 117:121-134.

Nishiwaki, S. 1969. Seasonal size variations of the pallial slit in the female Serpulorbis imbricatus (Prosobranchia, Vermetidae). Science Report, Tokyo Kyoiku Daigaku, Sect. B. 14 (208): 69-78.

Pilsbry, H. W. 1895. Catalogue of the marine mollusks of Japan, with descriptions of new species and notes on others collected by Frederick Stearns. Frederick Stearns, Detroit.

Schiaparelli, S., and R. Cattaneo-Vietti. 1999. Functional morphology of vermetid feeding-tubes. Lethaia 32:41-46.

Taylor, J. B. 1975. Planktonic prosobranch veligers of Kaneohe Bay. Ph.D. diss., University of Hawai'i at Mānoa, Honolulu.

Véliz, D., C. Guisado, and F. M. Winkler. 2001. Morphological, reproductive, and genetic variability among three populations of Crucibulum quiriquinae (Gastropoda: Calyptraeidae) in northern Chile. Mar. Biol. (Berl.) 139:527-534. 